\title{
Conferences as a learning arena in a pedagogical course
}

\author{
O. Førland, and R. Andersson, SFU bioCEED, University of Bergen
}

\begin{abstract}
Vi presenterer ein metode for å engasjere undervisarar i SoTL (Scholarship of Teaching and Learning) der undervisingsutvikling i eigen praksis vert delt gjennom deltaking på læringskonferansar. Utviklingsarbeidet blir gjort i ramma av eit pedagogisk kurs, der deltakarane gjennomfører gruppebaserte SoTL-prosjekt meiningsfulle for deira kontekst og praksis. Som del av kurset vert arbeidet sendt inn som bidrag til ein kollegavurdert læringskonferanse. Kursdesignet med kollegiale grupper og prosjekt i eigen kontekst sikrar ei viktig lokal forankring av SoTL-arbeidet. Konferansedeltaking som kursaktivitet tilfører ein ekstra dimensjon og en arena for læring og deling. Undervisarane utset arbeidet sitt for kritisk gransking og formidling i eit større miljø, og slik blir utviklingsarbeidet relevant og ekte - og ikkje berre ei oppgåve i eit kurs. Vi finn at deltakarane hadde stort utbytte av å presentere på læringskonferansar, og opplevde at konferansedeltaking gav meirverdi til kurset. Å presentere for eit interessert og kunnskapsrikt publikum var inspirerande og meiningsfullt, men undervisarane kjende òg på usikkerheit om kvalitet og kunnskapsnivå. Forebuande kursaktivitetar bidrog til å styrke sjølvtillit og kvalitet, og førebygge usikkerheit. Konferanse som kursaktivitet er krevjande for både deltakarar og kursleiar. Andre potensielle utfordringar er t.d. høgare terskel for å delta, risiko for refuserte bidrag, auka arbeidsmengde, kostnad og tidsbruk.
\end{abstract}

\section{INTRODUCTION}

The Centre for Excellence in Biology (bioCEED) was established in 2014 on the vision to educate tomorrows biologist in educations that integrate theoretical knowledge, practical skills and societal relevance. bioCEEDs project plan is grounded in the Scholarship of Teaching and Learning (SoTL) and a prerequisite for success is to build and sustain a scholarly and collegial learning culture among staff and students. Using the research culture as a model, bioCEED encourage academic teachers and educational staff to use teaching and learning theory, and document, describe and share their teaching practice and experience in the collegium (Andersson et al. 2017).

bioCEED started the first local Collegial Teaching and Learning Course (CTL, described in section 2) in 2015. Pedagogical courses are widely used to engage academic teachers in SoTL (i.e. Mårtensson et al. 2011), and the course provided a structured way for academic teachers and staff affiliated with bioCEED to engage in SoTL and get formal recognition. Pedagogical courses are an important tool to develop the participants' conceptions of teaching that influence their approaches to teaching, which again influence students approaches to learning (Trigwell \& Prosser 1996; Trigwell et al. 1999). The CTL course has developed over time from a local activity into a Faculty-wide course with participation from a variety of teaching and educational staff. In 2016 and 2018, the course included a teaching and learning (TL) conference as part of the course, and the course projects were submitted to peer reviewed conferences. The conference paper replaced the project report, and the conference presentation replaced the final course presentation, thus making the course work and the assessment public.

We were interested in how this was experienced by the course participants, as it is a novel approach in pedagogical courses. The paper presents findings from a small qualitative study on how the participants from two course cohorts experienced participating and presenting at a teaching and learning conference as part of the CTL course.

The aim and scope of our study and this paper is:

1. Outline the approach of using teaching and learning conferences as part of - and as a form of assessment - in pedagogical courses.

2. Investigate how course participants experienced participating and presenting at a teaching and learning conference as part of a pedagogical course.

3. Based on the participants and instructors' experiences discuss possibilities and challenges with this approach. 


\section{THE COLLEGIAL TEACHING AND LEARNING COURSE (CTL)}

\subsection{The Collegial Teaching and Learning in STEM Education course}

A key activity in bioCEED's work to build and sustain a collegial teaching culture is the pedagogical course Collegial Teaching and Learning - in STEM Education (CTL). It is a formal university pedagogy course (120h over 6 months) with a main focus on building and developing a collegial SoTL culture.

This course builds on a similar course developed at LTH, Lund University (Andersson \& Roxå 2014), and adapted to the bioCEED setting (Andersson \& Raaheim 2017). It is based on a socio-cultural perspective on teaching and learning in higher education and recognizes that the identity of academic teachers and their social positioning is built during the daily interactions among colleagues (Roxå et al. 2008; Trowler 2008). It is crucial that teachers not see teaching as private, however, going public with teaching is an action with potential social implications in the relation to your colleagues. Habitual collegial relations, unvoiced practices and assumptions about students and teaching could be hurdles for individual teachers to engage and move towards a more collegial teaching practice.

To address these potential hurdles, the course is group based (4-5 persons/group) with groups that share a common identity or interest (i.e. within same research group, or teaching large courses). This allows a focus on discussing, reading and writing about themes related to teaching and learning within the group member's immediate teaching practices. The course activities (Table 1) allow for collegial peer review and collegial reading of educational literature. These activities provide a common educational language, making collegial reflections on everyday experiences possible. Documentation and knowledge dissemination are essential to increase and ease adoption of new teaching strategies and practices. In line with this, the key component of the course is a group SoTL-project where the artefact being assessed is a scholarly written group report aimed at the local (departmental or institutional) level. The model with collegial groups engaging in meaningful projects in their working context address the importance of the local level for developing the collegial teaching culture (Roxå et al. 2008).

Table 1. Main course activities

\begin{tabular}{|l|l|l|}
\hline \multicolumn{1}{|c|}{ Activity } & \multicolumn{1}{|c|}{ Time } & \multicolumn{1}{c|}{ Assessment } \\
\hline Literature reading (individual) & $20 \mathrm{~h}$ & Written reflections, discussed in smaller groups. \\
\hline Project work (group, 4-5) & $\begin{array}{l}60 \mathrm{~h}(\mathrm{per} \\
\text { person) }\end{array}$ & $\begin{array}{l}\text { Written scholarly report, presented to whole course. } \\
\text { Peer feedback on draft version. }\end{array}$ \\
\hline Portfolio writing (individual) & $40 \mathrm{~h}$ & Written text. Peer feedback on final version. \\
\hline
\end{tabular}

\subsection{Going public with CTL project on teaching and learning conferences}

bioCEED encourage and support teachers and educational staff to participate and contribute in national educational arenas. In line with this, the 2015 CTL cohort was encouraged to submit their approved group projects to a TL conference (MNT2017) after the course. This functioned as a pilot to test the idea to make participating and presenting at a TL conference an integrated part of the course. All groups submitted and were accepted to the conference in the peer review process. Feedback from the participants was positive.

The course instructors have extensive experience organizing and reviewing contributions to TL conferences and considered it likely that also future project reports had potential to become conference contributions, both with regards to content and scholarly quality. Careful consideration was made when choosing the appropriate conferences. It was important that the conferences had teachers as the main audience and focused on teacher's inquiries into their own teaching practice. SoTL conferences like MNT and EuroSoTL2017 filled these criteria and had the additional advantage of being held in Scandinavia with organizers in the course instructors' network.

Although submitting to the conference was mandatory, acceptance was not required to pass the course. It was sufficient that the course instructors approved the conference paper. A "plan B" was also made, where course participants could present in the course in case of rejection. However, all groups got accepted, and the "plan B" was never employed. The course design was adjusted to support participants 
developing a conference contribution by strengthening collegial peer and instructor review of project and paper writing.

Finally, other important pre-requisites for including a conference as part of the course was the participants willingness to engage in this and the financial support of bioCEED and participants departments to cover conference costs.

\section{COURSE PARTICIPANTS EXPERIENCE OF CONFERENCE PARTICIPATION}

To further document the approach of including presenting and participating in TL conferences as part of a pedagogical course, we conducted a small qualitative study to capture the participants experience. We were especially interested in the conference experience, and not the course experience as a whole.

\subsection{Method}

Short interviews were conducted in 2019 by two of the three course instructors with 10 course participants from two subsequent CTL courses. The 2016/17 cohort participated in an international SoTL conference (EuroSoTL2017, Lund, Sweden), while the 2018/19 cohort participated in the national STEM conference (MNT2019, Troms $\varnothing$, Norway). Informants were recruited on a voluntary basis among all participants in the CTL 2016 and $2018(\mathrm{~N}=24)$. The informants are a mix of experienced scientific staff (2), more newly appointed scientific staff (4 associate professors) with some teaching experience, and early career researchers (4 PhDs/postdocs) with limited teaching experience.

The informants were asked open-ended questions about previous experience with TL conferences, the process and experience of presenting their group project at a TL conference, and about teaching and learning development and conference participation after the course. Interviews were analysed using a thematic analysis approach, to identify, organise and interpret themes from the interviews (King \& Brooks 2018). The third course instructors commented and provided input on the interview analysis.

\subsection{Results - The participants experience of "going public"}

We find that all the informants to a large extent had a positive experience with participating and presenting at a TL conference, and that they experienced it as an added value to the course. The most prominent overarching themes emerging from the interviews were: the conference as a new experience, the conference as a learning experience, and added value of conference to the course experience.

\section{A new experience}

For eight of the ten informants this was their first (peer reviewed) TL conference. These informants reported that they had not considered participating before, as this had not been relevant.

I was not aware of such conferences.

I had no reason to participate in such conferences.

All ten teachers described the conference as a positive experience. A majority also expressed that they were surprised by the experience - they were not aware of such conferences or that they were any good. Several informants mentioned the openness and inclusivity of the teaching and learning community and expressed that they enjoyed finding a new community and arena for teaching and learning.

At the conferences you meet the nerds that care.

There wasn't as many "egos" at the SoTL-conference as the conferences I normally attend-it was a very nice community.

Other recurring themes were the unfamiliar format of TL conferences compared to conferences in their own field. This was described as both positive and slightly negative as it led to some uncertainty.

All the informants mentioned some feeling of being apprehensive or slightly worried about the conference presentations, although not about the submission and review process. These worries were in relation to the quality of their project and choice of topic. Also, the informants felt apprehensive about operating within an arena unknown to them, outside their area of expertise. Several of the informants expressed a feeling of being on unfamiliar turf, and some a worry of not being taken seriously as "just a biology teacher". 


\section{A learning experience}

The informants all reported that they had put considerable effort into their projects due to the fact that it would be presented at a conference, often describing this to be a higher workload than what they expected in the course. However, this was not expressed as solely negative. Rather, it was to ensure that the quality of the work was good, and to lessen the worry around presenting on a theme seen as outside their area of expertise. Preparing for the conference during the course (peer feedback, course leader feedback) was described as important to build confidence, improve quality and relieve insecurity.

My group actually prepared more for this presentation than we normally do for conferences within our field.

Several informants described the whole SoTL project process (identify research questions, collect and analyse data, writing, peer feedback and review, and presentation at conference) as an important learning experience. They described learning a lot from others - both peers in the course and conference participants. Some informants also expressed that the process had led to a new way of thinking and talking about teaching and learning.

The conference opened my eyes - I had no idea you could do this kind of research on teaching and learning.

We were thrown into this field and into an established and important conference. It made us understand what it (SoTL) was all about.

\section{Added value of conference}

Presenting their project at an established peer-reviewed conference was highly appreciated by the participants. The fact that it was for real, and not just an assignment, added relevance and meaning. The informants described the conference participation as meaningful because they were contributing to something bigger. Sharing their work with others and experiencing that it was interesting and potentially useful for others was inspiring. The experience of presenting their work and participating offered an opportunity to network and get feedback from a wider community.

It was for real.

Authentic learning with positive backwash.

The added value of the conference for me, was all the things I learned from others.

Some of the more experienced teachers valued that a conference presentation was more prestigious, and therefor motivated them to work more on the project. This was expressed in a different way by the early career teachers, who saw the conference presentation as something that could positively affect their careers. This group of teachers also highlighted the dissemination training the conference offered.

This could go on my CV!

Several informants expressed surprise that their work actually was interesting for others and that their work was good enough to meet the standards of the conference.

Our work was interesting for others.

We got away with it!

\section{After the conference}

Half of the informants had participated in educational development projects and/or TL conferences after the course at the time of the interviews, and all informants expressed clear intentions to apply the knowledge and experience they gained from the course and conference in their own teaching. A majority of the informants are positive to participating in TL conferences in the future, preferable if and when they can contribute, and it is relevant to them.

\section{DISCUSSION}

The CTL course is one of a range of activities within bioCEED to build and sustain a scholarly and collegial culture for teaching and learning. The overarching goal is to contribute to institutional change through pedagogical discussion and dissemination within the institution and higher education in general. 
Collegial groups that engage in meaningful projects relevant for the own teaching address the importance of the local level for developing the collegial teaching culture (Roxå et al. 2008). Submitting their collegial work for critical review and feedback in a larger community provides a new arena for teachers to develop their scholarly practice. It can seem contradictory to move away from the local level when the teacher training aim is institutional change. However, we use the public level (TL conference) to enhance the local level (Ashwin \& Trigwell 2004). This approach allows for enhancement of individual knowledge, as well as institutional change and enhanced collective knowledge through dissemination within and beyond the institution (Fanghanel 2013).

The process and experience of conducting a SoTL project that will be presented to a larger community added to the learning experience of the course. Based on the participants description, the process also seems to lead to increased effort and quality. Participants valued the learning process of the SoTL project, which is also seen in their clear intentions to continue applying this knowledge and experience in the future. Our results show that all informants saw the conference as a positive experience that added meaning and relevance to the course work. They also reported a new awareness and appreciation for a larger community and teaching and learning conferences.

Their description of the initial apprehension and lack of confidence in what they felt to be a foreign territory - and the subsequent experience of mastering the situation, indicate that the participants have gained confidence and added legitimacy in pedagogical discussion and dissemination.

Although there are several positive outcomes from conferences as part of pedagogical course, we should also be aware of the potential challenging aspects of this approach. To be successful, these aspects need to be addressed. This approach is demanding for course participants and instructors, both in terms of effort, time and professional performance. This may lead to a higher threshold for attending the course. The risk of rejection adds to the pressure for both participants and instructors, and it is essential to have mitigating measures that relieves this pressure. A necessary prerequisite to make this approach sustainable is the support and commitment from the institution, to encourage staff to participate and provide opportunity by allowing staff to spend enough time and allocate financial support.

\section{REFERENCES}

Andersson, R., Eidesen, P.B., Fiksen, Ø., Førland, O., Stefansson, S., \& Vandvik, V. (2017). Korleis får professorar med på ein kollegial SoTL-kultur?, in Proceedings of MNT-konferansen 2017, Oslo.

Andersson, R., \& Raaheim, A. (2017). The Collegial Project Course: building a collegial scholarly culture scholarly, in Proceedings of the 14th International Society for the Scholarship of Teaching and Learning (ISSoTL) Conference, Calgary.

Andersson, R., and Roxå, T. (2014). The Collegial Project Course: a strategy for supporting SoTL through a socio cultural perspective, in Proceedings of the 11th International Society for the Scholarship of Teaching and Learning (ISSoTL) Conference, Quebec.

Ashwin, P., and Trigwell, K. (2004). Investigating staff and educational development. In P. Kahn \& D. Baume (Éd.), Enhancing staff \& educational development (p. 117-131). London; New York: RoutledgeFalmer.

Fanghanel, J. (2013). Going Public with Pedagogical Inquiries: SoTL as a Methodology for Faculty Professional Development. Teaching and Learning Inquiry, 1(1), 59-70. https://doi.org/10.2979/teachlearninqu.1.1.59

King, N., and Brooks, J. (2018). Thematic analysis in organisational research. In The sage handbook of qualitative business and management research methods (pp. 219-236). SAGE Publications Ltd, https://www.doi.org/10.4135/9781526430236

Mårtensson, K., Roxå, T., and Olsson, T. (2011). Developing a quality culture through the Scholarship of Teaching and Learning. Higher Education Research and Development, 30(1), 51-62. https://doi.org/10.1080/07294360.2011.536972

Roxå, T., Olsson, T., and Mårtensson, K. (2008). Appropriate use of theory in the scholarship of teaching and learning as a strategy for institutional development. Arts and Humanities in Higher Education.

Trigwell, K., and Prosser, M. (1996). Changing approaches to teaching: A relational perspective. Studies in Higher Education, 21, 275-284. doi:10.1080/03075079612331381211

Trigwell, K., Prosser, M., and Waterhouse, F. (1999). Relations between teachers' approaches to teaching and students' approaches to learning. Higher Education, 37, 57-70.

Trowler, P. (2008). Cultures and Change in Higher Education. Theories and practice. Gordonsville, Palgrave Macmillan. 